\title{
Association of Clara cell 10-kDa protein, spontaneous regression and sarcoidosis
}

\author{
N. Shijubo*, Y. Itoh**, K. Shigehara*, T. Yamaguchi***, K. Itoh***, Y. Shibuya*, R. Takahashi*, \\ T. Ohchi*, M. Ohmichi ${ }^{+}$, Y. Hiraga ${ }^{+}$, S. Abe*
}

Association of Clara cell 10-kDa protein, spontaneous regression and sarcoidosis. $N$. Shijubo, Y. Itoh, K. Shigehara, T. Yamaguchi, K. Itoh, Y. Shibuya, R. Takahashi, T. Ohchi, M. Ohmichi, Y. Hiraga, S. Abe. (C)ERS Journals Ltd 2000.

ABSTRACT: Sarcoidosis is a systemic granulomatous disorder with a high rate of spontaneous regression. Clara cell 10-kDa protein $(\mathrm{CC10})$, the predominant product of nonciliated bronchiolar epithelial cells, is a potent immunoregulatory and antiinflammatory agent.

CC10 levels were measured in sera and bronchoalveolar lavage (BAL) fluids from 31 sarcoidosis patients (nine progressive disease and 22 regressive disease) and their relevance to spontaneous regression investigated. The inhibitory effects of recombinant CC10 on interferon gamma (IFN- $\gamma$ ) production were examined using lipopolysaccharide (LPS)-stimulated sarcoid BAL fluid cells, and the blocking effects of monoclonal antibody $\mathrm{TY}-5$, directed against $\mathrm{CC10}$, on $\mathrm{CC10}$ function were also tested.

Serum and BAL fluid CC10 levels in the regressive disease group were significantly higher than those in the progressive disease group (serum, $p<0.05$; BAL fluid, $p<0.005$ ) and healthy subjects (serum, $\mathbf{p}<0.0001$; BAL fluid, $\mathbf{p}<0.005$ ). CC10 inhibited, in part, IFN- $\gamma$ production from LPS-stimulated sarcoid BAL fluid cells (CC10 inhibition: $\left.1,000 \mathrm{ng} \cdot \mathrm{mL}^{-1}, 30 \% ; 100 \mathrm{ng} \cdot \mathrm{mL}^{-1}, 14 \%\right)$. TY-5 restored IFN- $\gamma$ production by blocking $\mathrm{CC10}$ function.

Sarcoidosis patients with regressive disease showed increased Clara cell 10-kDa protein levels in their sera and bronchoalveolar lavage fluids. Clara cell 10-kDa protein may be a regulator of the inflammatory process in sarcoidosis.

Eur Respir J 2000; 16: 414-419.

\begin{abstract}
*Third Dept of Internal Medicine, Sapporo Medical University School of Medicine, Sapporo, **Dept of Laboratory Medicine, Asahikawa Medical College, Asahikawa, ***Dept of Laboratory Medicine, Jichi Medical School, Kawachi, ${ }^{+}$Dept of Respiratory Medicine, Sapporo Hospital of Hokkaido Railways Company, Sapporo, Japan.
\end{abstract}

Correspondence: N. Shijubo, Third Dept of Internal Medicine, Sapporo Medical University School of Medicine, South-1, West-16, Chuo-ku, Sapporo 060-8543, Japan. Fax: 81116131543

Keywords: Clara cell secretory protein Clara cell $10-\mathrm{kDa}$ protein

outcome

uteroglobin

Received: February 182000

Accepted after revision May 142000

This work was supported in part by Grantsin-Aid for Scientific Research from the Ministry of Education, Science and Culture [N.S. (10670556) and Y.I. (08672648)].
In sarcoidosis, the unknown causative agent leads to the accumulation of activated CD4+ lymphocytes releasing the T-helper cell 1 cytokines interleukin (IL)-2 and interferon gamma (IFN- $\gamma$ ) at sites of inflammation and granuloma formation [1]. Despite the systemic nature of the disease, T-cell and macrophage/monocyte activation are restricted to the involved organs. In $\sim 60 \%$ of patients with sarcoidosis, spontaneous regression is observed [2, 3]. Mechanisms downregulating inflammation are present in sarcoidosis, however, the prerequisites or mechanisms for induction of spontaneous regression are unknown.

Clara cell $10-\mathrm{kDa}$ protein $(\mathrm{CC} 10)$ is the predominant product of nonciliated bronchiolar epithelial cells (Clara cells) in respiratory and terminal bronchioles in the lung [4]. Human $\mathrm{CC} 10$ has been proven identical to human protein $1(P 1)[5]$ and uteroglobin (UG) [6]. CC10/UG possesses various biochemical and biological properties, including phospholipase $\mathrm{A}_{2}\left(\mathrm{PLA}_{2}\right)$ - [7] and phospholipase $\mathrm{C}$ (PLC)-inhibitory activity [8]. CC10 shows potent inhibition of IFN- $\gamma$, tumour necrosis factor- $\alpha$ (TNF- $\alpha$ ) and IL- $1 \beta[9,10]$. In addition, CC10 deficiency results in increased sensitivity to hyperoxia-induced lung injury by increasing pro-inflammatory cytokine expression [11]. The evidence has led to speculation that $\mathrm{CC} 10$ may function as a downregulator of airway inflammation.
The aims of the present study were to investigate $\mathrm{CC} 10$ levels in sera and bronchoalveolar lavage (BAL) fluids and their correlation with outcome of disease in sarcoidosis patients, and to test the inhibitory effects of $\mathrm{CC} 10$ on IFN- $\gamma$ production from sarcoid BAL fluid cells.

\section{Materials and methods}

Subjects

Only lifelong nonsmokers were selected for this study, because tobacco smoking has been associated with an $\sim 30 \%$ decrease in serum CC10 levels and an $\sim 50 \%$ decrease in BAL fluid CC10 levels $[12,13]$.

\section{Patients}

Thirty-one lifelong nonsmokers (mean age $47 \pm 20$ yrs; four male and 27 female) were selected from among 148 patients with sarcoidosis who visited our hospitals (Sapporo Medical University School of Medicine and Sapporo Hospital of Hokkaido Railways Company) between 1992 and 1996 (first series). They exhibited histological findings consistent with sarcoidosis (noncaseating epithelioid cell 
granulomas) in the lung, without evidence of mycobacterial, fungal or parasitic infection. None had a history of exposure to organic or inorganic materials known to cause granulomatous lung diseases. They had not received corticosteroid therapy.

Nine patients had stage 0 sarcoidosis (clear chest radiograph); 12 had stage 1 (hilar lymphadenopathy); seven had stage 2 (hilar lymphadenopathy and pulmonary infiltrates); and three had stage 3 (pulmonary infiltrates without hilar lymphadenopathy). They were followed-up for $\geq 3$ yrs.

In all stage 0 patients, extrapulmonary lesions (skirl, eye and/or lymph node) disappeared or regressed within 3 years without any therapy (regressive disease group). In six patients, the intrathoracic lesions progressed on chest radiography and/or chest computed tomography (CT) for $\geq 3$ yrs (progressive disease group), and, in 20, the intrathoracic lesions disappeared spontaneously or regressed within 3 yrs without any therapy (regressive disease group). Two patients were treated with corticosteroids for long periods due to progression of pulmonary or bone sarcoidosis (progressive disease group). In two patients (stage 1 and stage 2), the ocular lesions greatly improved with short-term (4-8 week) corticosteroid therapy; within 3 yrs after therapy, intrathoracic lesions relapsed in one patient (progressive disease group), and the remaining patient did not have any recurrence (regressive disease group). The progressive $(\mathrm{n}=9)$ and regressive disease group $(n=22)$ were divided. In the first series, serum and BAL fluid samples were simultaneously collected from untreated patients with sarcoidosis at the time of diagnosis.

In order to evaluate the effects of recombinant $\mathrm{CC} 10$ on IFN- $\gamma$ production from BAL fluid cells, eight untreated patients were selected. They visited the hospitals between July 1997 and December 1998 (second series). All of them were histologically confirmed to have sarcoidosis. In the second series, five patients were in stage 1 and three in stage 2 (mean age $32 \pm 5$ yrs; three male and five female). BAL fluid samples were collected at the time of diagnosis.

\section{Healthy subjects}

Serum samples were obtained from 64 healthy lifelong nonsmokers (mean age $42 \pm 9$ yrs; 15 male and 49 female). BAL fluid samples were obtained from 15 healthy lifelong nonsmokers (mean age $28 \pm 7$ yrs; 10 male and five female). The healthy subjects had no history of respiratory diseases. Their chest radiography films revealed no abnormalities and spirometric tests showed normal results (vital capacity $>80 \%$ of the predicted value; forced expiratory volume in one second (FEV1) $>70 \%$ pred). Informed consent was obtained from the patients and healthy subjects.

\section{Bronchoalveolar lavage procedure}

Three $50-\mathrm{mL}$ aliquots of sterile $0.9 \%$ saline were instilled into a bronchus in the right middle lobe through a fibreoptic bronchoscope. The BAL fluid was recovered by gentle suction immediately after infusion of each aliquot. BAL fluid samples were centrifuged for $10 \mathrm{~min}$ at $400 \times \mathrm{g}$. The recovered cells were analysed for total (using a cytometer) and differential cell counts (500 cells were counted). The supernatants centrifuged for $30 \mathrm{~min}$ at $550 \times g$. The supernatants from this last centrifugation were cryopreserved at $-30^{\circ} \mathrm{C}$ until use. Albumin concentrations in BAL fluids were determined by immunoprecipitation and laser nephelometry. The results of BAL fluid analysis of healthy subjects and sarcoidosis patients (first and second series) are shown in table 1.

\section{Expression and purification of recombinant human Clara cell 10-kDa protein}

Using a pET expression system, recombinant human CC10 was obtained from Escherichia coli culture as described previously $[8,14]$. Recombinant human CC10 was purified using anti-CC $10 / P 1$ monoclonal antibody (MoAb) 6D4-conjugated Sepharose 4B (Pharmacia, Uppsala, Sweden) and reverse-phase high-performance liquid chromatography (Bondasphere mm C4-300A; Waters, Milford, MA, USA), as described previously [8, 14]. The 20 amino-terminal amino acid residues of purified recombinant $\mathrm{CC} 10$ were identical to those of native protein except for an additional methionine at the aminoterminus of recombinant human $\mathrm{CC} 10$, when determined with gas-phase amino acid sequencer model PPSQ-10 (Shimazu, Kyoto, Japan) according to the manufacturer's instructions.

\section{Monoclonal antibodies to human Clara cell $10-k D a$ protein/protein 1}

Nine MoAbs (6D4, TY-1, TY-2, TY-3, TY-4, TY-5, TY6 , TY-7 and TY-8) to human CC10/P1 were produced [14]. CC10 is a homodimer consisting of 70 -amino acid subunits arranged in an antiparallel fashion and connected by two disulphide bonds. Epitopes recognized by these clones were analysed as described previously [14]. The clones TY-1 and TY-2 recognized residues 61-68, which are exposed to solvent. A sensitive sandwich enzymelinked immunosorbent assay (ELISA) was developed using TY-1 and TY-2, selected from among the MoAbs $[14,15]$. The clone TY-5 recognized residues $7-16$ of $\mathrm{CC} 10$, which make up the hydrophobic cavity of $\mathrm{CC} 10$, possibly associated with chemical-binding function. The binding of TY-5 to CC10 prevents the other clones from

Table 1. - Characteristics of bronchoalveolar lavage fluid analysis

\begin{tabular}{|c|c|c|c|}
\hline & \multirow{2}{*}{$\begin{array}{l}\text { Healthy } \\
\text { subjects }\end{array}$} & \multicolumn{2}{|c|}{ Sarcoidosis } \\
\hline & & $\begin{array}{l}\text { First } \\
\text { series }\end{array}$ & $\begin{array}{l}\text { Second } \\
\text { series }\end{array}$ \\
\hline Subjects $n$ & 15 & 31 & 8 \\
\hline Recovery rate \% & $66.3 \pm 10.8$ & $63.5 \pm 13.5$ & $67.2 \pm 10.3$ \\
\hline $\begin{array}{l}\text { Total cell counts } 10^{4} \\
\text { cells } \cdot \mathrm{mL}^{-1}\end{array}$ & $12.8 \pm 7.1$ & $15.8 \pm 12.4$ & $17.9 \pm 10.3$ \\
\hline $\begin{array}{l}\text { Alveolar macrophages } 10^{4} \\
\text { cells } \cdot \mathrm{mL}^{-1}\end{array}$ & $10.6 \pm 5.8$ & $10.3 \pm 7.7$ & $11.4 \pm 5.6$ \\
\hline $\begin{array}{l}\text { Lymphocytes } 10^{4} \\
\mu \mathrm{g} \cdot \mathrm{mL}^{-1}\end{array}$ & $2.1 \pm 0.5$ & $5.5 \pm 2.6^{*}$ & $6.4 \pm 3.9 * *$ \\
\hline $\begin{array}{l}\text { Neutrophils } 10^{4} \\
\mu \mathrm{g} \cdot \mathrm{mL}^{-1}\end{array}$ & $0.04 \pm 0.02$ & $0.09 \pm 0.05$ & $0.10 \pm 0.06$ \\
\hline $\begin{array}{l}\text { Albumin } 10^{4} \\
\text { cells } \cdot \mathrm{mL}^{-1}\end{array}$ & $39.1 \pm 12.1$ & $47.4 \pm 18.7$ & $52.8 \pm 20.3$ \\
\hline $\begin{array}{l}\mathrm{CC} 1010^{4} \\
\text { cells } \cdot \mathrm{mL}^{-1}\end{array}$ & $757 \pm 418$ & $1100 \pm 772$ & $1054 \pm 689$ \\
\hline
\end{tabular}

Data are presented as mean $\pm \mathrm{SD} .{ }^{*}: \mathrm{p}<0.005 ; * *$ : $<0.01$ versus healthy subjects. 
binding, suggesting that TY-5 induces strong conformational changes in CC10 [14].

\section{Quantitation of Clara cell 10-kDa protein}

CC10 concentrations were measured via an ELISA employing MoAbs TY-1 and TY-2 to human CC10/P1, as described previously [15]. Briefly, plastic immunoplates (Nunc, Copenhagen, Denmark) were coated with MoAb TY-2 $\left(1 \mathrm{mg} \cdot \mathrm{L}^{-1}\right)$ in $50 \mu \mathrm{M}$ carbonate buffer ( $\left.\mathrm{pH} 9.6\right)$ overnight at $4^{\circ} \mathrm{C}$. Unbound MoAb was removed by washing with $0.05 \%$ Tween 20 in $0.05 \mathrm{M}$ phosphatebuffered saline (PBS-T) (pH 7.0) and then coated with $100 \mu \mathrm{L} 1 \%$ bovine serum albumin in PBS-T (BSA-PBS$\mathrm{T})$. To this, $100 \mu \mathrm{L}$ of standard or diluted samples were added and allowed to react with the coated antibody for $60 \mathrm{~min}$ at $37^{\circ} \mathrm{C}$. Unbound antigen was removed by washing with PBS-T. Biotinylated MoAb TY-1 $(100 \mu \mathrm{L}$, $\left.1 \mathrm{mg} \cdot \mathrm{L}^{-1}\right)$ in BSA-PBS-T was added, and the mixture incubated for $60 \mathrm{~min}$ at $37^{\circ} \mathrm{C}$. The material was then washed with the same buffer, $100 \mu \mathrm{L}$ of streptavidin/ peroxidase-conjugated goat antimouse immunoglobulin (diluted 1:1,000 in BSA-PBS-T) added and the mixture again incubated for another $30 \mathrm{~min}$ at $37^{\circ} \mathrm{C}$. After repeated washing with the same buffer, the unbound enzyme conjugate was removed. At this point, $100 \mu \mathrm{L}$ enzyme substrate containing $1 \mathrm{mg} \cdot \mathrm{mL}^{-1} o$-phenylenediamine in citrate buffer ( $\mathrm{pH} 5.0$ ) and $0.03 \%$ (volume/ volume) hydrogen peroxide was added. Enzyme activity was measured by determining absorbance at $490 \mathrm{~nm}$ after terminating the reaction with $150 \mu \mathrm{L} 1.0 \mathrm{M}$ sulphuric acid. Purification of standard antigen was performed as previously described $[13,16]$. Mean coefficients of variation of intra-assay and interassay accuracy were 5.2\% (range $4.7-5.9 \%$ ) and $7.2 \%$ (range $6.2-8.6 \%$ ), respectively [15]. CC10 concentrations can be determined in the range $5 \mathrm{pg} \cdot \mathrm{mL}^{-1}-20.5 \mathrm{ng} \cdot \mathrm{mL}^{-1}$. This ELISA was 10 times more sensitive than one using MoAb 6D4 to CC10 and polyclonal antibody to $\mathrm{CC} 10 / P 1[15,17]$. All assays were performed in duplicate.

\section{Cell culture}

BAL fluid cells were obtained from the eight patients with sarcoidosis. The cells were washed three times with Roswell Park Memorial Institute (RPMI)-1640 medium containing $10 \%$ foetal calf serum (FCS). Cells were cultured at $1 \times 10^{6}$ cells $\cdot \mathrm{mL}^{-1}$ in RPMI-1640 supplemented with $10 \%$ heat-inactivated $\left(56^{\circ} \mathrm{C}, 30 \mathrm{~min}\right) \mathrm{FCS}, 2 \mathrm{mM} \mathrm{l-}$ glutamine, and $0.1 \%$ gentamycin in 24 -well microtitre plates (Nunc, Roskilde, Denmark). Media and supplements were purchased from Gibco (Paisley, UK). The authors tested IFN- $\gamma$ production by sarcoid BAL fluid cells with stimulation by lipopolysaccharide (LPS; E coli serotype 0111 B4, Sigma Aldrich Chemi GmbH, Steinheim, Germany) at concentrations of $10 \mathrm{ng} \cdot \mathrm{mL}^{-1}, 100 \mathrm{ng} \cdot \mathrm{mL}^{-1}, 1$ $\mu \mathrm{g} \cdot \mathrm{mL}^{-1}$ and $10 \mu \mathrm{g} \cdot \mathrm{mL}^{-1}$. LPS effectively induced IFN $-\gamma$ in sarcoid BAL fluid cells at a concentration of $1 \mu \mathrm{g} \cdot \mathrm{mL}^{-1}$. Thus cells were stimulated by $1 \mu \mathrm{g} \cdot \mathrm{mL}^{-1}$ LPS in the absence or presence of recombinant CC10 (100 or 1,000 $\left.\mathrm{ng} \cdot \mathrm{mL}^{-1}\right)$ and cultured for $48 \mathrm{~h}$.

In order to block CC10 function, MoAb TY-5 (25 $\mu \mathrm{g} \cdot \mathrm{mL}^{-1}$ ) was added at the initiation of the culture of LPSstimulated BAL fluid cells with $1,000 \mathrm{ng} \cdot \mathrm{mL}^{-1} \mathrm{CC} 10$.
When isotype-matched MoAb $\left(25 \mu \mathrm{g} \cdot \mathrm{mL}^{-1}\right)$ was added as a negative control, no significant differences in IFN- $\gamma$ concentrations were found in LPS-stimulated sarcoid BAL fluid cells with or without isotype-matched MoAb in the presence of $1,000 \mathrm{ng} \cdot \mathrm{mL}^{-1} \mathrm{CC} 10$. Samples were obtained from the supernatants and cryopreserved at $-80^{\circ} \mathrm{C}$ until use.

\section{Measurement of interferon gamma}

Human IFN- $\gamma$ ELISA kits were purchased from Biosource International (Camarillo, CA, USA). IFN- $\gamma$ concentrations can be determined in the range $4-1,000 \mathrm{pg} \cdot \mathrm{mL}^{-1}$. Mean coefficients of variation of intra-assay and interassay precision were 5.5 and $6.0 \%$, respectively. The assay system showed no cross-reactivity with other human cytokines.

\section{Statistical analysis}

Data are expressed as means \pm SD. The Mann-Whitney Utest or paired t-test was used to compare paired sets of data. Pearson least squares linear regression analysis was used to determine correlation. A p-value of $<0.05$ was considered significant.

\section{Results}

Serum and bronchoalveolar lavage fluid Clara cell 10$k D a$ protein levels and their correlation

The serum CC10 levels of patients with sarcoidosis $\left(19.5 \pm 8.60 \mathrm{ng} \cdot \mathrm{mL}^{-1}\right.$, range $\left.6.92-42.3 \mathrm{ng} \cdot \mathrm{mL}^{-1}\right)$ were significantly increased as compared with healthy subjects $\left(11.6 \pm 3.85 \mathrm{ng} \cdot \mathrm{mL}^{-1}\right.$, range 5.16-22.4 ng. $\left.\mathrm{mL}^{-1} ; \mathrm{p}<0.0001\right)$ (fig. 1). There were no significant differences in serum CC10 levels according to radiological stage (stage 0 , $19.2 \pm 11.0 \mathrm{ng} \cdot \mathrm{mL}^{-1}$; stage $1,18.7 \pm 6.2 \mathrm{ng} \cdot \mathrm{mL}^{-1}$; stage 2 , $21.4 \pm 11.0 \mathrm{ng} \cdot \mathrm{mL}^{-1}$; and stage $3,18.8 \pm 5.0 \mathrm{ng} \cdot \mathrm{mL}^{-1}$ ).

There was no significant difference in CC10 levels in BAL fluids from healthy subjects $\left(757 \pm 418 \mathrm{ng} \cdot \mathrm{mL}^{-1}\right)$ and sarcoidosis patients $\left(1,100 \pm 772 \mathrm{ng} \cdot \mathrm{mL}^{-1}\right)$ (table 1 and fig. 2). No significant difference in BAL fluid CC10/albumin ratios was found between healthy subjects $(18.7 \pm 9.1$ $\left.\mathrm{ng} \cdot \mu \mathrm{g}^{-1}\right)$ and sarcoidosis patients $\left(25.8 \pm 16.6 \mathrm{ng} \cdot \mu \mathrm{g}^{-1}\right)$. There were no significant differences in BAL fluid CC10 levels according to radiological stage (stage $0,1,110 \pm 671$ $\mathrm{ng} \cdot \mathrm{mL}^{-1}$; stage $1,1,050 \pm 780 \mathrm{ng} \cdot \mathrm{mL}^{-1}$; stage $2,1,330 \pm$ $1,040 \mathrm{ng} \cdot \mathrm{mL}^{-1}$; and stage $3,676 \pm 311 \mathrm{ng} \cdot \mathrm{mL}^{-1}$ ). No significant differences in BAL fluid CC10/albumin ratios were found according to radiological stage (stage 0, 26.5 \pm 13.1 $\mathrm{ng} \cdot \mu \mathrm{g}^{-1}$; stage $1,24.2 \pm 18.7 \mathrm{ng} \cdot \mu \mathrm{g}^{-1}$; stage $2,29.6 \pm 20.0$ $\mathrm{ng} \cdot \mu \mathrm{g}^{-1}$; and stage $\left.3,20.6 \pm 14.0 \mathrm{ng} \cdot \mu \mathrm{g}^{-1}\right)$.

There was a significant positive correlation in $\mathrm{CC} 10$ levels between sera and BAL fluids from sarcoidosis patients $(\mathrm{r}=0.759, \mathrm{p}<0.0001)$ (fig. 3 ).

\section{Relationship of Clara cell $10-k D a$ protein levels to clinical outcome}

Relationships of serum and BAL fluid CC10 levels to clinical outcome were analysed in the 31 patients with sarcoidosis. The mean CC10 levels in serum $(21.7 \pm 9.13$ $\left.\mathrm{ng} \cdot \mathrm{mL}^{-1}\right)$ and BAL fluid $\left(1,360 \pm 751 \mathrm{ng} \cdot \mathrm{mL}^{-1}\right)$ in the regressive disease group were significantly higher than those 


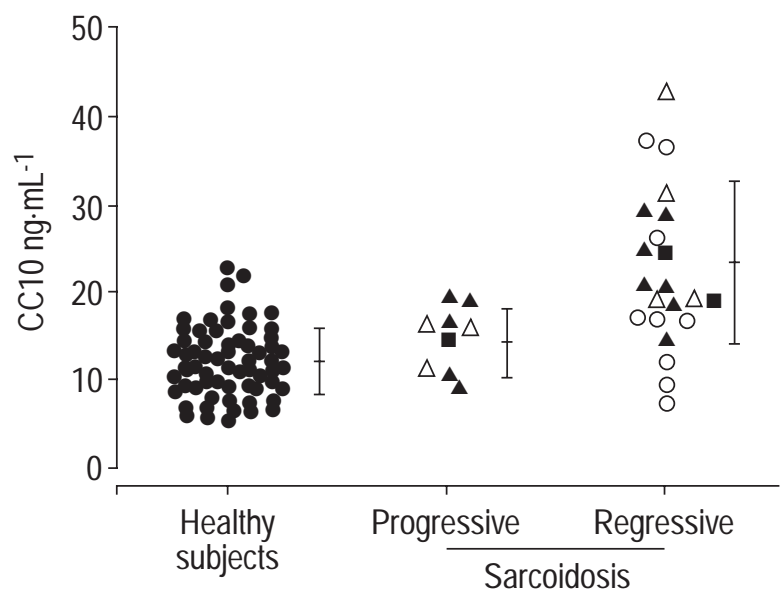

Fig. 1. - Clara cell 10-kDa protein (CC10) concentrations in sera from healthy and sarcoidosis patient nonsmokers. A significant difference was found in serum $\mathrm{CC} 10$ levels between the healthy subjects and regressive group sarcoidosis patients $(\mathrm{p}<0.0001)$. $\bigcirc$ : stage $0 ; \boldsymbol{\Lambda}$ : stage $1 ; \triangle$ : stage 2; $\mathbf{\square}$ : stage 3 . Horizontal and vertical bars indicate the mean and SD.

in the progressive disease group (serum, $14.2 \pm 3.70 \mathrm{ng} \cdot \mathrm{mL}^{-1}$, $\mathrm{p}<0.05$; BAL fluid, $\left.458 \pm 328 \mathrm{ng} \cdot \mathrm{mL}^{-1}, \mathrm{p}<0.005\right)$ and those in the healthy subjects ( $\mathrm{p}<0.0001$ and $\mathrm{p}<0.005$, respectively). In contrast, there were no significant differences in serum or BAL fluid CC10 levels between the progressive disease group and healthy subjects. In addition, the mean BAL fluid CC10/albumin ratio $\left(31.7 \pm 15.0 \mathrm{ng} \cdot \mu^{-1}\right)$ was significantly higher in the regressive disease group than in the progressive group $\left(11.3 \pm 10.3 \mathrm{ng} \cdot \mu^{-\mathrm{P}}, \mathrm{p}<0.005\right)$ and healthy controls $(\mathrm{p}<0.005)$. There was no significant difference in BAL fluid CC10/albumin ratios between the progressive disease group and healthy controls.

Effects of recombinant Clara cell 10-kDa protein on interferon gamma production in bronchoalveolar lavage fluid cells

LPS-stimulated sarcoid BAL fluid cells produced IFN- $\gamma$ $\left(871 \pm 382 \mathrm{ng} \cdot \mathrm{mL}^{-1}\right)$. CC10 reduced IFN- $\gamma$ production by LPS-stimulated sarcoid BAL fluid cells (CC10 1,000 $\mathrm{ng} \cdot \mathrm{mL}^{-1}: 30.3 \pm 17.6 \%$ inhibition, range $11.7-54.9 \%$; CC10 $100 \mathrm{ng} \cdot \mathrm{mL}^{-1}: 14.0 \pm 14.8 \%$ inhibition, range $\left.1.2-46.5 \%\right)$ (fig. 4). However, there was no significant difference in the percentage of inhibition of IFN- $\gamma$ production by $\mathrm{CC} 10$ in LPS-stimulated sarcoid BAL fluid cells between the stage 1 and stage 2 disease groups. When correlation of the percentage of inhibition of IFN- $\gamma$ production by $\mathrm{CC} 10$ (100 and $\left.1,000 \mathrm{ng} \cdot \mathrm{mL}^{-1}\right)$ was analysed with numbers of alveolar macrophages and lymphocytes, there was no significant correlation of the percentage of inhibition with cell subsets. The MoAb TY-5 restored IFN- $\gamma$ production by blocking $\mathrm{CC} 10$ function (fig. 5).

\section{Discussion}

Significantly increased levels of serum and BAL fluid CC10 in sarcoidosis patients with regressive disease compared with those with progressive disease and with healthy subjects were found in the present study. Recombinant CC10 inhibited IFN- $\gamma$ production by LPS-stimulated

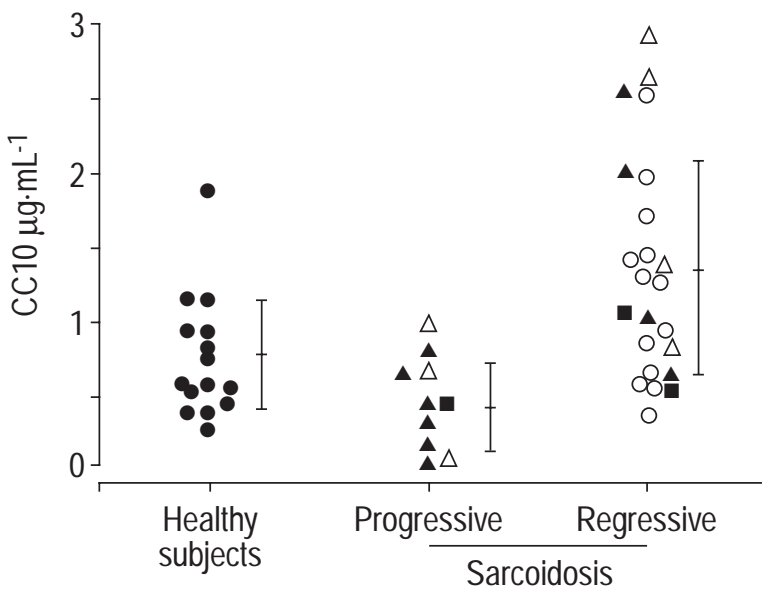

Fig. 2. - Clara cell 10-kDa protein (CC10) concentrations in bronchoalveolar lavage (BAL) fluids from healthy and sarcoidosis patient nonsmokers. A significant difference was found in BAL fluid CC10 levels between the healthy subjects and regressive group sarcoidosis patients $(\mathrm{p}<0.005)$. $\bigcirc$ : stage $0 ; \mathbf{\Delta}$ : stage $1 ; \triangle$ : stage 2 ;

: stage 3. Horizontal and vertical bars indicate the mean and SD.

sarcoid BAL fluid cells and MoAb TY-5 to CC10 restored IFN- $\gamma$ production by blocking $\mathrm{CC} 10$ function.

CC10 plays an important immunoregulatory and antiinflammatory role in the lung. It has been shown to inhibit the activity of PLA $\mathrm{PA}_{2}$, a key enzyme in inflammatory phenomena [6]. JoHNSTON et al. [11] reported increased sensitivity to hyperoxia-induced lung injury and an exaggerated inflammatory response in CC10-deficient mice. In an animal model, $\mathrm{CC} 10$ messenger ribonucleic acid was upregulated by IFN- $\gamma[16]$. CC10 production by human airway epithelial cells was stimulated by TNF- $\alpha$ [18]. Several lines of evidence support the hypothesis that $\mathrm{CC} 10$ functions as a downregulator and a counterregulator of inflammation.

CC10 levels in sera and BAL fluids have been reported in various lung diseases [13, 19-24]. Decreases in CC10 levels have been found in the BAL fluids of patients with asthma [19], idiopathic pulmonary fibrosis [20], and chronic obstructive pulmonary disease [21] and in the

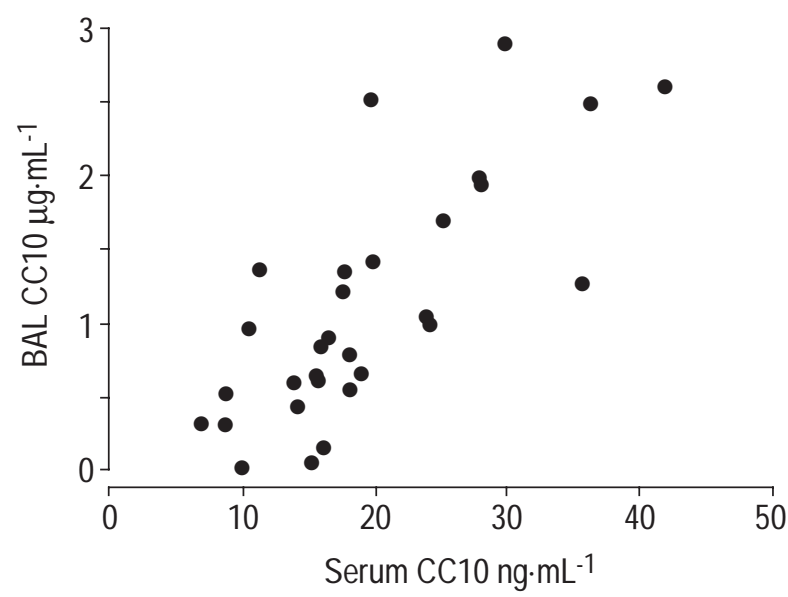

Fig. 3. - Correlation in Clara cell 10-kDa protein (CC10) levels between sera and bronchoalveolar lavage (BAL) fluids from sarcoidosis patient nonsmokers $(\mathrm{n}=31)$. A significant positive correlation was found $(\mathrm{r}=0.759, \mathrm{p}<0.0001)$. 


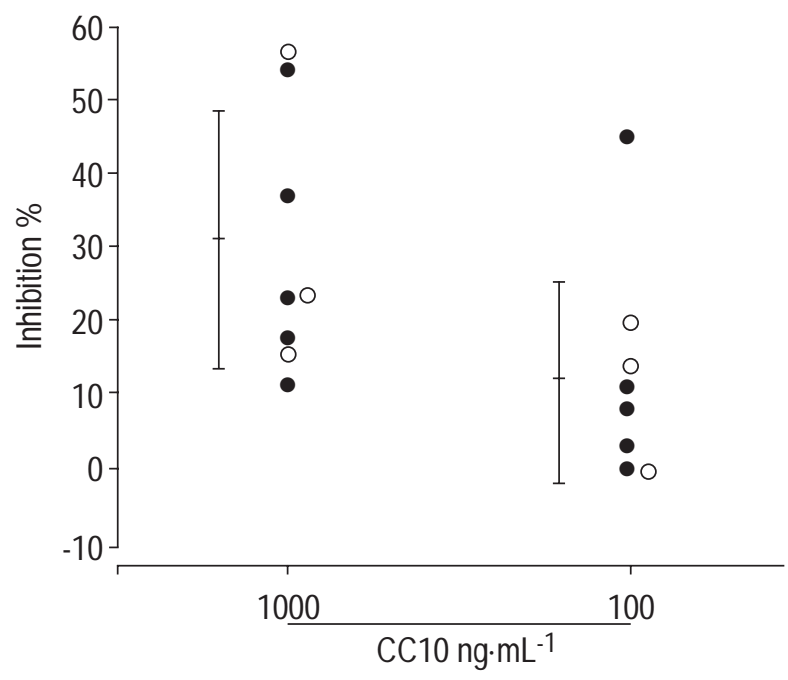

Fig. 4. - Inhibitory effects of Clara cell $10-\mathrm{kDa}$ protein $(\mathrm{CC} 10)$ on interferon- $\gamma$ production by lipopolysaccharide-stimulated bronchoalveolar lavage fluid cells obtained from eight patients with sarcoidosis. : stage $1 ; \bigcirc$ : stage 2 . Horizontal and vertical bars indicate the mean and SD.

sera of patients with asthma [22], chronic obstructive pulmonary disease [21] and bacterial pneumonia [23]. Increases in CC10 level have been found in the BAL fluids of patients with asbestosis [24]. A recent observation showed reduced numbers of CC10-positive epithelial cells in the small airways of patients with asthma [25]. The present study documented increased $\mathrm{CC} 10$ levels in the sera of patients with sarcoidosis, but not in BAL fluids, consistent with a prior report [21]. Increased CC10 levels in sera and BAL fluids from sarcoidosis patients with regressive disease were documented in the present study. In this study, control BAL fluid samples were obtained from considerably younger healthy subjects. It is difficult to obtain BAL fluid samples for healthy subjects from ageand sex-matched sarcoidosis patients, because all life-long nonsmoker sarcoidosis patients were considerably old and many of the patients were female with very few male patients. This study also demonstrated a positive correlation between serum and BAL fluid CC10 levels in sarcoidosis patients, suggesting that serum CC10 levels reflect $\mathrm{CC} 10$ production in lung cells under disease condition as well as in healthy subjects $[12,21]$.

In the present study, recombinant $\mathrm{CC} 10$ reduced, in part, IFN- $\gamma$ production by LPS-stimulated sarcoid BAL fluid cells. Native $\mathrm{CC} 10 / P 1$ inhibited IFN- $\gamma$ production by phytohaemagglutinin-stimulated peripheral blood mononuclear cells from a healthy donor [9]. CC10 reduced the biological action of IFN- $\gamma$ such as antiviral activity and phagocytosis-stimulating activity [9]. Native CC10/P1 induced PLA2-mediated inhibition of fibroblast migration [20]. Recombinant CC10 inhibited PLA2 and PLC activities in a dose-dependent manner $[8,26]$. Recombinant CC10/UG blocked fibroblast-conditioned mediumstimulated cancer cell migration in a dose-dependent manner [27]. Recombinant CC10/UG suppressed extracellular matrix invasion by normal and cancer cells that expressed high-affinity receptors for CC10/UG [28, 29]. Several lines of evidence indicate that there are no signi-

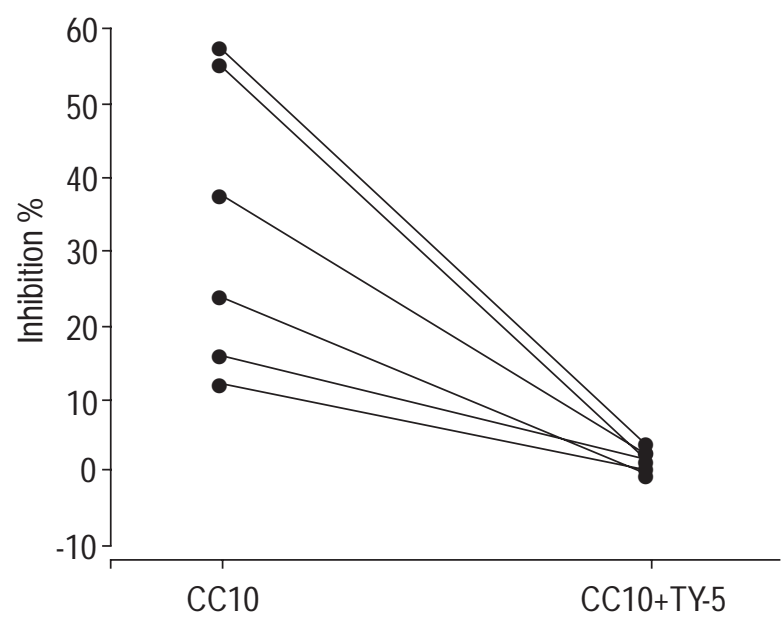

Fig. 5. - Neutralizing activity of monoclonal antibody TY-5 to Clara cell $10-\mathrm{kDa}$ protein $(\mathrm{CC} 10)$ on $\mathrm{CC} 10$ function. Interferon gamma levels were measured in the supernatants of lipopolysaccharide-stimulated bronchoalveolar lavage fluid cells obtained from six patients with sarcoidosis in the presence of $\operatorname{CC10}\left(1,000 \mathrm{ng} \cdot \mathrm{mL}^{-1}\right)$ with or without TY-5 $\left(25 \mathrm{mg} \cdot \mathrm{L}^{-1}\right)$.

ficant functional differences between native and recombinant $\mathrm{CC} 10$. In addition, although speculative, the inhibitory effects of $\mathrm{CC} 10$ on IFN- $\gamma$ production from sarcoid BAL fluid cells may depend on the expression of highaffinity CC10-binding receptors of BAL fluid cells.

The present study demonstrated that MoAb TY-5, specific to human $\mathrm{CC} 10$, restored IFN- $\gamma$ production by blocking CC10 function. TY-5 recognized residues 7-16 of CC10, which make up the hydrophobic cavity [14]. The binding of TY-5 to CC10 prevented the other MoAbs from binding to $\mathrm{CC} 10$, suggesting that TY-5 induced strong conformational change in CC10 [14]. To the authors' knowledge, this is the first report demonstrating that $\mathrm{MoAb}$ specific to human $\mathrm{CC} 10$ restores the inhibitory function of $\mathrm{CC} 10$ by neutralizing $\mathrm{CC} 10$. The evidence suggests that $\mathrm{CC} 10$ is a downregulator in sarcoidosis patients and that high levels of CC10 in inflamed lesions could reduce inflammation and cytokine production from sarcoid lesions, resulting in disease regression in sarcoidosis. The lungs and eyes are the organs most commonly affected in sarcoidosis; interestingly, CC10 immunoreactivity has been found in the eyes [30] as well as in Clara cells in the lung. The A38G polymorphism of human $\mathrm{CC} 10$ has been found in asthmatic children [31]. This polymorphism has been associated with reduced levels of serum CC10 and an increased risk of developing asthma [31]. In addition, homozygous 38A subjects demonstrated reduced plasma CC10 levels as compared to heterozygotes and homozygous $38 \mathrm{G}$ subjects within the nonasthmatic group [31]. Although speculative, the A38G polymorphism in the untranslated region of the $\mathrm{CC} 10$ gene may be related to $\mathrm{CC} 10$ production in response to IFN- $\gamma$ and TNF- $\alpha$, reflected in the clinical outcome of sarcoidosis. Additional studies are needed to evaluate the association of $\mathrm{CC} 10$ levels with the A38G polymorphism of patients with sarcoidosis.

In conclusion, serum and bronchoalveolar lavage fluid samples from sarcoidosis patients with regressive disease 
contain significantly higher levels of Clara cell 10-kDa protein, and human Clara cell $10-\mathrm{kDa}$ protein inhibits interferon gamma production by lipopolysaccharide-stimulated sarcoid bronchoalveolar lavage fluid cells. The evidence indicates the importance of Clara cell $10-\mathrm{kDa}$ protein as a regulator of airway inflammation in sarcoidosis patients.

\section{References}

1. American Thoracic Society. Statement of sarcoidosis. Am J Respir Crit Care Med 1999; 160: 736-755.

2. Shijubo N, Imai K, Shigehara K, Hinoda AS. Circulating soluble intercellular adhesion molecule-1 (sICAM-1) in patients with sarcoidosis. Clin Exp Immunol 1996; 106: 549-554.

3. Zissel G, Homolka J, Schlaak J, Schlaak M, MüllerQuerheim J. Anti-inflammatory cytokine release by alveolar macrophages in pulmonary sarcoidosis. $\mathrm{Am} \mathrm{J}$ Respir Crit Care Med 1996; 154: 713-719.

4. Singh G, Katyal SL, Gottron SA. Antigenic, molecular and functional heterogeneity of Clara cell secretory proteins in the rat. Biochim Biophys Acta 1985; 829: 156159.

5. Okutani R, Itoh Y, Hirata H, Kasahara T, Mukaida N, Kawai T. Simple and high-yield purification of urine protein 1 using immunoaffinity chromatography: evidence for the identity of urine protein 1 and human Clara cell 10-kilodalton protein. J Chromatogr 1992; 577: 25-35.

6. Mantile G, Miele L, Cordella-Miele E, Singh G, Katyal $\mathrm{SL}$, Mukherjee AB. Human Clara cell $10 \mathrm{kDa}$ protein is the counterpart of rabbit uteroglobin. J Biol Chem 1993; 268: 20343-20351.

7. Levin SW, Butler JD, Schumacher UK, Wightman PD, Mukherjee AB. Uteroglobin inhibits phospholipase $\mathrm{A}_{2}$ activity. Life Sci 1986; 38: 1813-1819.

8. Okutani R, Itoh Y, Yamaguchi T, Kawai K, Singh G Preparation and characterization of human recombinant protein 1/Clara cell $10 \mathrm{kDa}$ protein. Eur J Clin Chem Clin Biochem 1996; 34: 691-696.

9. Dierynck I, Bernard A, Roels H, Ley MD. Potent inhibition of both human interferon- $\gamma$ production and biological activity by the Clara cell protein CC16. Am J Respir Cell Mol Biol 1995; 12: 205-210.

10. Dierynck I, Bernard A, Roels H, De Ley M. The human Clara cell protein: biochemical and biological characterisation of a natural immunosuppressor. Mult Scler 1996; 1: 385-387.

11. Johnston CJ, Mango GW, Finkelstein JN, Stripp BR. Altered pulmonary response to hyperoxia in Clara cell secretory protein deficient mice. Am J Respir Cell Mol Biol 1997; 17: 147-155.

12. Shijubo N, Itoh Y, Yamaguchi T, et al. Serum and BAL Clara cell protein (CC10) levels and CC10-positive bronchiolar cells are decreased in smokers. Eur Respir J 1997; 10: $1108-1114$.

13. Hermans C, Bernard A. Lung epithelium-specific proteins: characteristics and potential applications as markers. Am J Respir Crit Care Med 1999; 159: 646-678.

14. Yamaguchi T, Yamada T, Okutani R, Shijubo N, Singh G, Itoh Y. Characterization of monoclonal antibodies to human protein 1/Clara cell 10 kilodalton protein. Clin Chem Lab Med 1999; 37: 631-637.

15. Yamaguchi T, Itoh Y, Yamada T, Itoh K. Development of a sensitive enzyme immunoassay for protein 1/Clara cell
$10 \mathrm{kDa}$ protein using monoclonal antibodies. Rinsho Byori 1999; 47: 467-472 (in Japanese)

16. Magdaleno SM, Wang G, Jackson KJ, et al. Interferon- $\gamma$ regulation of Clara cell gene expression: in vivo and in vitro. Am J Physiol 1997; 272: L1142-L1151.

17. Ishii S, Itoh Y, Okunaki R, Asano Y, Kawai T. Development of an enzyme-linked immunosorbent assay for protein 1. Contrib Nephrol 1993; 101: 71-77.

18. Yao XL, Levine SJ, Cowan MJ, Logun C, Shelhamer JH. Tumor necrosis factor- $\alpha$ stimulates human Clara cell secretory protein production by human airway epithelial cells. Am J Respir Cell Mol Biol 1998; 19: 629-635.

19. Van Vyve T, Chanez P, Bernard A, et al. Protein content in bronchoalveolar lavage fluid of patients with asthma and control subjects. J Allergy Clin Immunol 1995; 95: 60-68.

20. Lesur O, Bernard A, Arsalane $\mathrm{K}$, et al. Clara cell protein (CC16) induces a phospholipase $\mathrm{A}_{2}$-mediated inhibition of fibroblast migration in vitro. Am J Respir Crit Care Med 1995; 152: 290-297.

21. Bernard A, Marchandise FX, Depelchin S, Lauwerys R, Sibille Y. Clara cell protein in serum and bronchoalveolar lavage. Eur Respir J 1992; 5: 1231-1238.

22. Shijubo N, Itoh Y, Yamaguchi T, et al. Serum levels of Clara cell $10-\mathrm{kDa}$ protein are decreased in patients with asthma. Lung 1999; 177: 45-52.

23. Nomori H, Hiroo H, Fuyuno G, Kobayashi R, Morinaga S, Hirabayashi Y. Protein 1 (Clara cell protein) serum levels in healthy subjects and patients with bacterial pneumonia. Am J Respir Crit Care Med 1995; 152: 746-750.

24. Lesur O, Bernard AM, Begin RO. Clara cell protein (CC16) and surfactant-associated protein A (SP-A) in asbestos-exposed workers. Chest 1996; 109: 467-474.

25. Shijubo N, Itoh Y, Yamaguchi T, et al. Clara cell proteinpositive epithelial cells are reduced in small airways of asthmatics. Am J Respir Crit Care Med 1999; 160: 930933.

26. Anderson O, Nordlund-Moller L, Barnes HJ, Lund J. Heterologous expression of human uteroglobin/polychlorinated biphenyl-binding protein: determination of ligand binding parameters and mechanism of phospholipase $\mathrm{A}_{2}$ inhibition in vitro. $J$ Biol Chem 1994; 269 : 19081-19087.

27. Leyton J, Manyak MJ, Mukherjee AB, Miele L, Mantile G, Patierno SR. Recombinant human uteroglobin inhibits the in vitro invasiveness of human metastatic prostate tumor cells and the release of arachidonic acid stimulated by fibroblast-conditioned medium. Cancer Res 1994; 54 : 3696-3699.

28. Kundu GC, Mandal AK, Zhang Z, Mantile-Selvaggi G, Mukherjee AB. Uteroglobin (UG) suppresses extracellular matrix invasion by normal and cancer cells that express the high affinity UG-binding proteins. $J$ Biol Chem 1998; 273: 22819-22824.

29. Zhang Z, Kundu GC, Panda D, et al. Loss of transformed phenotype in cancer cells by overexpression of the uteroglobin gene. Proc Natl Acad Sci USA 1999; 96: 39633968.

30. Zhang Z, Zimonjic DB, Popescu NC, et al. Human uteroglobin gene: structure, subchromosomal localization, and polymorphism. DNA Cell Biol 1997; 16: 7383 .

31. Laing IA, Hermans C, Bernard A, Burton PR, Goldblatt J, Le Souef PN. Association between plasma CC16 levels, the A38G polymorphism, and asthma. Am J Respir Crit Care Med 2000; 161: 124-127. 